\title{
The Impact of Online Food Applications during the Covid-19 Pandemic
}

\author{
Sevenpri Candra ${ }^{*}$, Monica Ayudina², Muhammian Aga Arashi² \\ ${ }^{1}$ Management Department, BINUS Business School Undergraduate Program, Bina Nusantara University, \\ Jakarta 11480, Indonesia \\ ${ }^{2}$ Management Department, BINUS Online Learning, Bina Nusantara University, Jakarta 11480, Indonesia
}

\begin{abstract}
In early May 2020, the Government of Indonesia announced that the Covid-19 outbreak was categorised as a pandemic and imposed several rules in order to minimise the negative impacts arising from this pandemic. This has caused people's routines to change, especially in terms of travelling and eating. This study aims to determine the online purchase intention and actual buy of food and beverages purchased using an online food application, especially during the Covid-19 pandemic. A structural equation model is used to perform the analysis in this research. This study was conducted by sending an online questionnaire to members of the public who were in a work from home or split office situation and had made a purchase through an online food delivery application during the Covid-19 pandemic. The sample used for analysis in the study consisted of 446 respondents. The results showed that subjective norms, e-service quality, and health consciousness had an impact on these online purchase intention activities. However, food and beverage quality is not a factor that can trigger online purchase intentions. On the other hand, there is a significant relationship between online purchase intentions and actual buy, so it can be concluded that the higher the online purchase intention, the more the actual buy will be increasingly realised. Online food delivery service providers and food and beverage sellers can increase promotions to increase online purchase intentions and the frequency of actual buy.
\end{abstract}

Keywords: e-service quality; Food quality; Health consciousness; Online purchase intention; Subjective norm

\section{Introduction}

The Covid-19 pandemic has had a far-reaching impact on not only human health but almost all the fabric of human life. Covid-19 is a respiratory infectious disease similar to pneumonia that is caused by the coronavirus (Taylor, 2020; WHO, 2005). Globally, in February 2020, more and more countries confirmed cases and deaths caused by Covid-19. Likewise, in Indonesia at the beginning of March 2020, there were patients who were positive with Covid-19 (Kemenkes Republik Indonesia, 2020). As the number of patients increased and Covid-19 was easily transmitted, the DKI Jakarta Government issued a policy so that employees who work can do activities from home. Following the increasing and expanding infections between regions and the high numbers of cases and deaths in Indonesia, the Government of Indonesia imposed large-scale social restrictions, with the exception of offices and strategic agencies meeting criteria for defence and security, public order, food needs, fuel, oil and gas, health services, finance, communications, industry, 
exports and imports, logistics distribution, and other basic needs (Putsarna, 2020). In essence, the quarantine of this region aimed to enforce physical distancing to be able to minimise the increasing number of cases in several major cities in Indonesia (Amirullah, 2020; Tamtomo, 2020).

Large-scale social restrictions meant that estimated economic growth in 2020 fell to $2.3 \%$ (Sembiring, 2020). The decline in economic activity has the potential to put pressure on financial institutions because credit cannot be paid, and companies will experience difficulties from revenue due to the Covid-19 pandemic. The decline in Indonesia's economic growth is due to weakening economic activity in several sectors, including hotels and tourism, airlines, meetings, incentives, conferences, exhibitions (MICE), bars and restaurants, cinemas and concerts, sports, malls and retail, consumer electronics, automotive, and fuel (Pramudita, 2020). The bar and restaurant or food and beverage sector is one of the sectors that experienced weakening in economic activity, but the sector still has the potential to make an economic turnover even though it is not under normal conditions. One of the ways to do this is to prioritise online food delivery sales and takeout (Berawi, 2020; Cahyadi, 2020).

The food and beverage sector is one of the business sectors affected by the adjustments to government regulations designed to temporarily stop dine-in services, and this spurred restaurants to operate via online food delivery (CNN Indonesia, 2020). A qualitative study of the sociocultural attitudes towards of customers food online food delivery revealed several aspects that affected their consumption, including comfort, saving time, customer access, and social experiences to share when bringing food to eat at home (Blow et al., 2019). In 2019, an estimated 1.92 billion people purchased goods or services online, and electronic retail sales surpassed 3.5 trillion U.S. dollars worldwide (Coppola, 2021). This figure keeps climbing every year, as internet access and the adoption of technology are rapidly increasing. Indonesia is the $10^{\text {th }}$ largest e-commerce growth country, with 78 percent growth (Badan Pusat Statistik, 2019; KOMINFO, 2019). Online business is predicted to continue to thrive in Indonesia for the next few years. This is predicted to occur due to the increasing purchasing power of the community and better levels of technological literacy and internet access throughout Indonesia (Annur, 2020a; Annur, 2020b). Based on data from Moka, which is a startup provider of digital cashier services in Indonesia, there was an increase in food or beverage purchases by the online food delivery method by $7 \%$ from January to February 2020 (Soenarso, 2020). This can be seen in the increase in transactions in Grab Food online food delivery, which increased by 4\% in March 2020 (Hastuti, 2020). McDonald's, as an international fast food restaurant, also experienced growth in non-cash transactions on drive-thru or take-away services of as much as four times, with an average daily transaction value rising around $170 \%$ after the first week of being informed of a pandemic in Indonesia (Pertiwi, 2020). There was an increase in online food delivery because the government recommended not to leave the house to minimise the spread of Covid-19.

Today's delivery service is not only performed by conventional restaurants, as the technology world has made it easier for us to deliver online through applications on smartphones: Go-Jek has the Go-Food feature, Grab has the Grab Food feature, and WhatsApp chat can place an order directly with the seller. The ease of online food delivery can help people to continue to make purchases without leaving home during the Covid-19 pandemic. This is in line with an increase in demand of $10 \%$ for services through Go-Food and Grab Food (Annur, 2020b). In addition, some food and beverage merchants offer online food delivery services through the WhatsApp application; this is done to maximise reach to 
consumers during the Covid-19 pandemic (Ismaya Gourmet Shop, 2020; JW Marriot Hotel Official, 2020; Sate Taichan "Goreng" Official, 2020; Berawi, 2021).

Based on the above explanation, transaction data for people's desires to shop online in a pandemic are increasing. According to Nystrand and Olsen (2020) said that online purchase intentions occur because of the subjective norms held by the buyer. This study uses the theory of planned behaviour, with an extension of the framework of the variables for self-efficacy, subjective norms, and hedonic and utilitarian eating values. Hypothesis relationships are tested using a structural equation model. The results of this study indicate that attitude and intention affect the consumption of functional foods. The research also suggests that the food industry or food and beverages need to functionally increase the value of food to be commercially successful.

Other research conducted by Kusumaningsih et al. (2019) says that online purchase intentions occur because of an attachment to health consciousness. This research uses the structural equation model and examines a population of respondents who have the intention to buy organic food by taking samples from a population of 150 respondents. The result is that health consciousness and environmental attitude impact attitudes towards purchasing organic foods, while subjective norms are not a factor that actively influences organic food purchases. The research provides advice by increasing knowledge about the benefits of organic food for the health and environment of the customer, so that increasing consumption of organic food can be achieved. Moreover, research from Xiao et al. (2018) explains that online purchase intentions occur because of the influence between food amd beverage quality and customer buying interest.

Based on several previous studies, it can be seen that the phenomenon of online purchase intention can be predicted by subjective norms, health consciousness, food and beverage quality, and e-service quality (Wee et al., 2014; Memery et al., 2015; Abdulsahib et al., 2019; Kusumaningsih et al., 2019). By looking at online purchase intentions, we can see the actual buy of transactions that will be carried out in online food applications (Sulek and Hensley, 2004; Rauniar et al., 2014; Memery et al., 2015; Ueasangkomsate and Santiteerakul, 2016; Curvelo et al., 2019; Candra et al., 2020a; Nystrand and Olsen, 2020). This research was conducted to see the actual buy of food and beverage transactions through online food applications during the Covid-19 pandemic in several regions in Indonesia. The benefit of the research is to help better understand the conditions and tendencies of consumers in the community who are in the condition of working from home or using a split office and use online food delivery application services during the Covid-19 pandemic. Moreover, this study will enrich the context of research related to the utilisation of online food applications, especially during the Covid-19 pandemic and in the context of the Indonesian state. This is important because there are still limited studies available about online food delivery, especially in Indonesia (Rahmaningtyas et al., 2017; Kusumaningsih et al., 2019; Suhartanto et al., 2019).

A subjective norm is a personal view of actions that are encouraged and influenced by other parties that are considered important by the person (Shin and Hancer, 2016; Asvial et al., 2021). A subjective norm is a part of normative belief, where the belief refers to the beliefs and views of people that are important to an individual. Sometimes it may not only be the views but also the pressure from other parties that are important to an individual. Subjective norms can be linked to online purchase intentions, and based on research conducted by Hasbullah et al. (2016) using the statistical method of multiple regression analysis, subjective norms have a significant impact on online purchase intentions. Referring to Kusumaningsih et al. (2019) to study the relationship between subjective norms and online purchase intentions using the statistical analysis method, structural 
equation modelling, the results are similar: namely, there is a relationship between subjective norms and purchase intention. The greater the influence of the subjective norm, the stronger the influence on one's purchase intention. Due to the encouragement of the closest people to oneself, such as family, close friends, and one's community, a higher purchase intention will make someone buy something. This gives us the first hypothesis that can be established for this study:

H1: There is a relationship between subjective norms and online purchase intention.

Based on research from Xiao et al. (2018), customers have a tendency to seek nutritious food that has health value, so food and beverage quality has an impact on purchase intentions. In addition, Suhartanto et al. (2019) showed that food and beverage quality has several levels of assessment, such as whether the appearance of food and drinks is interesting, there are diverse types, the tastes of food and beverages are delicious, and there are choices of healthy food or drinks. his research reveals that food and beverage quality has an impact on online loyalty. Furthermore, a study by Sulek and Hensley (2004) shows that food and beverage quality has many characteristics, such as a diverse menu, good food taste, good food appearance, and healthy food choices; this study establishes a relationship between food and beverage quality and purchase intention. Based on these three studies, it can be hypothesis that:

H2: There is a relationship between food \& beverage quality and online purchase intention.

A study by Ahmed et al. (2017) found that online shopping businesses in China can achieve high buying interest as a result of e-service quality, which has an impact on purchase intention. Moreover, Kalia et al. (2016) explained that ease of use, fast responses, informativeness, and a sense of security when using e-services can increase purchase intention, to show a relationship between e-service quality and purchase intention. Based on the two studies, it can be hypothesis that:

H3: There is a relationship between e-service quality and online purchase intention.

Consumers are beginning to have an awareness of how healthy the food they consume is in terms of nutrition, health, and quality, and this can affect the criteria for purchasing food (Chen, 2009). Before consumers can make purchases, of course they will refer to purchase intentions for what they will consume. Based on research conducted by Meireles (2018) regarding the relationship between health consciousness and purchase intentions in the population of Lisbon, Portugal, a correlation was found between health consciousness and purchase intention in purchasing organic food in local supermarkets in Portugal. Other research by Abdulsahib et al. (2019) studied hypotheses about whether health consciousness has a significant relationship to purchase intentions for healthy food. That research uses the statistical method of partial least square analysis on a sample of the population data collection in Iraq. The result is that health consciousness and purchase intentions of healthy food are related. It can be concluded that if health consciousness is correlated to purchase intentions, it will have the slightest relationship. Thus, another hypothesis can be established for this study:

H4: There is a relationship between health consciousness and online purchase intentions.

Online shopping has become a rapidly developing trend in the world, especially with the presence of information and communications technology (Ofori and Appiah-Nimo, 2019). Of course, before someone chooses something to buy, there is a purchase intention 
first. Purchase intention represents the level of probability that an actual buy will occur by consumers; it is how consumers think and consider buying something (Wee et al., 2014; Candra et al., 2020b). By increasing purchase intention, the possibility of actual buy actions will become more apparent. Research by Ofori and Appiah-Nimo (2019) studied whether there is a correlation between purchase intention and actual buy in online shopping activities. The research was conducted using the SEM-PLS method, which found that there was a strong relationship between purchase intention and actual buying behaviour. It can be concluded from these studies that there is a tendency for actual buy to be closely related to purchase intention. Thus, a final hypothesis can be established for this study:

H5: There is a relationship between online purchase intention and actual buy.

\section{Methods}

This study discusses factors that can influence consumer behaviour in work from home or split office situations when using online food delivery applications during the Covid-19 Pandemic. In detail, it can be seen in Figure 1. The target respondents in this study were people who did work from home or split office work during the Covid-19 pandemic and had used online food delivery during the Covid-19 pandemic. The measurement scale that will be used on the questionnaire is a five-point Likert scale with levels of agreement and disagreement (Sekaran and Bougie, 2016). The sampling technique used was snowball sampling (Zikmund et al., 2013; Taherdoost, 2016; Kirchherr and Charles, 2018). The use of snowball sampling is expected to maximise the number of respondents to be achieved. In addition, it is hoped that a more diverse range of respondents will be obtained because the population can come from various sources. With this limited condition, the snowball sampling approach is expected to be more optimal. The number of samples used in this study is 10 times the number of indicators in the study, so the minimum sample study is 270 (Gefen et al., 2000). To answer the problems and hypotheses that have been developed, the structural equation model will be used as a data analysis method, and the software used is Warppls 7.0 (Hair et al., 2019; Kock, 2020). The research model is more suitable to be analysed by using the structural equation model since the sample size is limited, and for several other reasons: the relationship between constructs is linear, the model can be improved with the "trimming theory" technique, which is to eliminate paths that are not in the model, and the calculation of model fit is required.

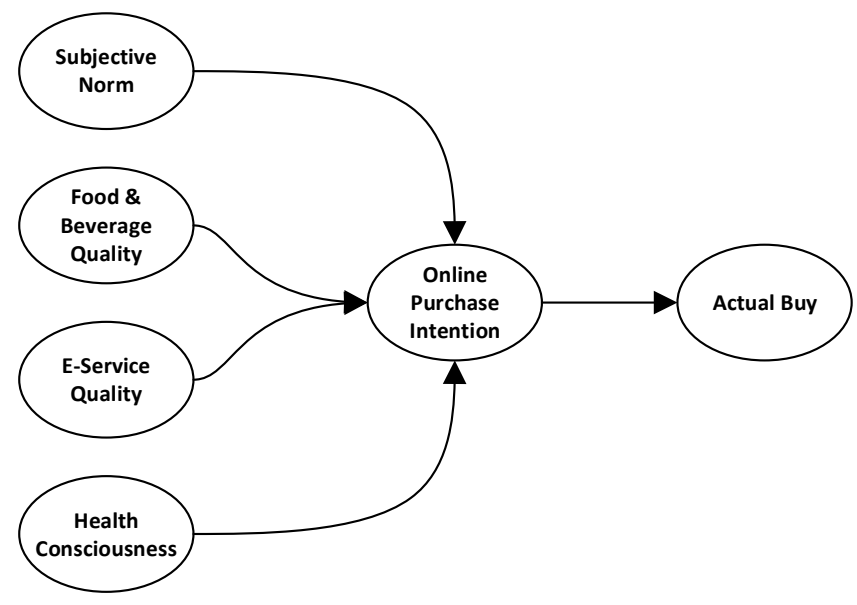

Figure 1 Research model 


\section{Results and Discussion}

The process of data collection was performed online using Microsoft Forms. From the results of questionnaires conducted, 572 respondents participated in the study. After cleaning the data, only 446 forms from the questionnaire results could be categorized as valid and used for further analysis. Based on the demographic characteristics, it can be concluded that male and female respondents almost equally used online food delivery applications during the Covid-19 pandemic. Meanwhile, when viewed in terms of age, the majority are in the age range of 17 to 25 years. This illustrates reasonable conditions because the use of smartphone-based applications is common in that age range. Indeed, those who use these applications more are private employees. For more complete demographic conditions, see Table 1.

Table 1 Demographic characteristics

\begin{tabular}{|c|c|c|c|c|c|}
\hline Profile Respondents & Frequency & Percentage & Profile Respondents & Frequency & Percentage \\
\hline Sex & & & Monthly Expenditure & & \\
\hline Female & 188 & $42.152 \%$ & Under IDR 1 mio & 26 & $5.830 \%$ \\
\hline Male & 258 & $57.848 \%$ & IDR 1 - 2.9 mio & 96 & $21.525 \%$ \\
\hline Age & & & IDR 3 - 4.9 mio & 131 & $29.372 \%$ \\
\hline $17-25$ & 174 & $39.013 \%$ & IDR 5 - 5.9 mio & 75 & $16.816 \%$ \\
\hline $26-34$ & 79 & $17.713 \%$ & Above IDR 5.9 mio & 118 & $26.457 \%$ \\
\hline $35-43$ & 89 & $19.955 \%$ & Education & & \\
\hline $44-52$ & 63 & $14.126 \%$ & High School & 80 & $17.937 \%$ \\
\hline Above 52 & 41 & $9.193 \%$ & Diploma & 62 & $13.901 \%$ \\
\hline Occupation & & & Undergraduate & 196 & $43.946 \%$ \\
\hline $\begin{array}{l}\text { Private } \\
\text { Employees }\end{array}$ & 221 & $49.552 \%$ & Master Degree & 86 & $19.283 \%$ \\
\hline $\begin{array}{l}\text { College } \\
\text { Students }\end{array}$ & 84 & $18.834 \%$ & Doctoral Degree & 22 & $4.933 \%$ \\
\hline Civil Servants & 72 & $16.143 \%$ & \multirow{2}{*}{\multicolumn{3}{|c|}{$\begin{array}{l}\text { Use of the Online Food Delivery } \\
\text { (Choice can be more than one) }\end{array}$}} \\
\hline Housewives & 34 & $7.623 \%$ & & & \\
\hline $\begin{array}{l}\text { Self- } \\
\text { Employed }\end{array}$ & 33 & $7.399 \%$ & GoFood & 335 & $51.538 \%$ \\
\hline Others & 2 & $0.448 \%$ & GrabFood & 289 & $44.462 \%$ \\
\hline Province & & & eMarketplace & 11 & $1.692 \%$ \\
\hline Banten & 41 & $9.193 \%$ & Others & 15 & $2.308 \%$ \\
\hline DKI Jakarta & 101 & $22.646 \%$ & \multicolumn{3}{|c|}{$\begin{array}{l}\text { Family Members (in the same } \\
\text { house) }\end{array}$} \\
\hline Jawa Barat & 227 & $50.897 \%$ & 1 - 2 members & 80 & $17.937 \%$ \\
\hline Jawa Tengah & 12 & $2.691 \%$ & 3 - 4 members & 212 & $47.534 \%$ \\
\hline Jawa Timur & 16 & $3.587 \%$ & 5 - 6 members & 133 & $29.821 \%$ \\
\hline Yogyakarta & 4 & $0.897 \%$ & $\begin{array}{l}\text { More than } 6 \\
\text { members }\end{array}$ & 21 & $4.709 \%$ \\
\hline Outside Java & 45 & $10.090 \%$ & & & \\
\hline
\end{tabular}

The next analysis is with the structural equation model with Warppls 7.0 software. There are two stages of evaluation, namely the measurement model and the structural model (Hair et al., 2014; Urbach and Ahlemann, 2010). The test results for the measurement model and structural model can be seen in Table 2 and Table 3. Table 4 explains the results of data processing with WarpPLS. 
Table 2 Measurement model test result

\begin{tabular}{|c|c|c|c|c|}
\hline \multirow[b]{2}{*}{ Constructs } & \multicolumn{2}{|c|}{ Validity Test } & \multicolumn{2}{|c|}{ Reliability Test } \\
\hline & $\begin{array}{l}\text { Loading } \\
\text { Factor }\end{array}$ & AVE & $\begin{array}{l}\text { Composite } \\
\text { Reliability }\end{array}$ & $\begin{array}{c}\text { Cronbach's } \\
\text { Alpha }\end{array}$ \\
\hline E-Service Quality & & 0.431 & 0.9 & 0.878 \\
\hline $\begin{array}{l}\text { Online food delivery applications make it easy to get } \\
\text { food \& beverages. }\end{array}$ & 0.641 & & & \\
\hline $\begin{array}{l}\text { Online food applications make it easy for me to find } \\
\text { what I need. }\end{array}$ & 0.727 & & & \\
\hline Online food applications are easy to use. & 0.705 & & & \\
\hline Online food applications can always be used. & 0.671 & & & \\
\hline Online food applications are responsive. & 0.682 & & & \\
\hline The delivered order is as promised. & 0.700 & & & \\
\hline The order is delivered promptly. & 0.729 & & & \\
\hline $\begin{array}{l}\text { Product availability is according to online food } \\
\text { application. }\end{array}$ & 0.665 & & & \\
\hline Estimated food \& beverage shipment is as promised. & 0.599 & & & \\
\hline $\begin{array}{l}\text { Online food applications provide recommendations } \\
\text { according to my shopping habits. }\end{array}$ & 0.615 & & & \\
\hline $\begin{array}{l}\text { My personal information from online food } \\
\text { applications is not shared. }\end{array}$ & 0.481 & & & \\
\hline Payment through online food applications is safe. & 0.625 & & & \\
\hline Food \& Beverage Quality & & 1.676 & 0.806 & 0.677 \\
\hline The food \& beverages have a good appearance. & 0.792 & & & \\
\hline There are many varieties of food and beverages. & 0.718 & & & \\
\hline The food \& beverages have a good taste. & 0.786 & & & \\
\hline $\begin{array}{l}\text { There are healthy food choices where I order my } \\
\text { food \& beverages. }\end{array}$ & 0.545 & & & \\
\hline Subjective Norm & & 0.879 & 0.936 & 0.863 \\
\hline $\begin{array}{l}\text { People closest to me think I should buy food \& } \\
\text { beverages online. }\end{array}$ & 0.938 & & & \\
\hline $\begin{array}{l}\text { People closest to me expect me to buy food \& } \\
\text { beverages online. }\end{array}$ & 0.938 & & & \\
\hline Health Consciousness & & 0.728 & 0.889 & 0.812 \\
\hline $\begin{array}{l}\text { It's important for me that food \& beverages that I } \\
\text { consume do not make me overweight. }\end{array}$ & 0.869 & & & \\
\hline $\begin{array}{l}\text { It's important for me that food \& beverages that I } \\
\text { consume provide health benefits. }\end{array}$ & 0.802 & & & \\
\hline $\begin{array}{l}\text { It's important for me that food \& beverages that I } \\
\text { consume help me to control my weight. }\end{array}$ & 0.886 & & & \\
\hline Online Purchase Intention & & 0.865 & 0.951 & 0.922 \\
\hline I expect to buy food \& beverages within 1 week. & 0.898 & & & \\
\hline I want to buy food \& beverages within 1 week. & 0.960 & & & \\
\hline I intend to buy food \& beverages within 1 week. & 0.932 & & & \\
\hline Actual Buy & & 0.61 & 0.823 & 0.675 \\
\hline How often do you buy food \& beverages in 1 week? & 0.858 & & & \\
\hline $\begin{array}{l}\text { How many transactions in } 1 \text { week were to buy food } \\
\text { \& beverages? }\end{array}$ & 0.802 & & & \\
\hline $\begin{array}{l}\text { Since Covid- } 19 \text { was identified in Indonesia, I have } \\
\text { been buying food \& beverages through online food } \\
\text { applications. }\end{array}$ & 0.670 & & & \\
\hline
\end{tabular}


Table 3 Structural model test result

\begin{tabular}{|c|c|c|}
\hline Structural Model Test & Rules & Results \\
\hline \multicolumn{3}{|l|}{ Model Fit Indicator } \\
\hline Average Path Coefficient (APC) & $\mathrm{P}<0.05$ Good & $\begin{array}{c}0.217 \\
\mathrm{P}<0.001\end{array}$ \\
\hline Average R-Squared (ARS) & $\mathrm{P}<0.05$ Good & $\begin{array}{l}0.218 \\
\mathrm{P}<0.001\end{array}$ \\
\hline Average Adjusted R-Square (AARS) & $\mathrm{P}<0.05$ Good & $\begin{array}{c}0.214 \\
\mathrm{P}<0.001\end{array}$ \\
\hline Average Block VIF (AVIF) & AVIF $<5$ Good & 1.349 \\
\hline Average Full Collinearity VIF (AFVIF) & $\begin{array}{l}\text { AFVIF < } 5 \text { Good } \\
\text { Small } 0.1-0.24\end{array}$ & 1.433 \\
\hline Tenenhaus GoF (GoF) & $\begin{array}{c}\text { Medium } 0.25-0.35 \\
\text { Large Above } 0.35\end{array}$ & 0.383 \\
\hline Simpson's Paradox Ratio (SPR) & SPR $>0.7$ Good; Ideal if $=1$ & 1 \\
\hline R-Squared Contribution Ratio (RSCR) & RSCR $>0.9$ Good; Ideal if $=1$ & 1 \\
\hline Statistical Suppression Ratio (SSR) & SSR > 0.7 Good & 1 \\
\hline Nonlinear Bivariate Causality Direction Ratio (NLBCDR) & NLBCDR > 0.7 Good & 1 \\
\hline \multicolumn{3}{|l|}{ R-Squared } \\
\hline E-Service Quality to Online Purchase Intention & & 0.045 \\
\hline Subjective Norm to Online Purchase Intention & Weak 0.19 & 0.105 \\
\hline Food \& Beverage Quality to Online Purchase Intention & Moderate 0.33 & 0.018 \\
\hline Health Consciousness to Online Purchase Intention & Substantial 0.19 & 0.019 \\
\hline Online Purchase Intention to Actual Buy & & 0.249 \\
\hline \multicolumn{3}{|l|}{ Effect Sizes } \\
\hline E-Service Quality to Online Purchase Intention & & 0.045 \\
\hline Subjective Norm to Online Purchase Intention & Weak 0.02; & 0.105 \\
\hline Food \& Beverage Quality to Online Purchase Intention & Medium 0.15; & 0.018 \\
\hline Health Consciousness to Online Purchase Intention & Large 0.35 & 0.019 \\
\hline Online Purchase Intention to Actual Buy & & 0.249 \\
\hline
\end{tabular}

Table 4 Hypotheses results

\begin{tabular}{lccl}
\hline \multicolumn{1}{c}{ Hypotheses } & p-Value & Path Coefficients & \multicolumn{1}{c}{ Decisions } \\
\hline E-Service Quality to Online Purchase Intention & 0.001 & 0.145 & Support \\
Subjective Norm to Online Purchase Intention & 0.001 & 0.278 & Support \\
Food \& Beverage Quality to Online Purchase Intention & 0.084 & 0.065 & Not Support \\
Health Consciousness to Online Purchase Intention & 0.022 & 0.095 & Support \\
Online Purchase Intention to Actual Buy & 0.001 & 0.499 & Support \\
\hline
\end{tabular}

Social pressure from the closest person to the respondent, who is considered important, can influence respondents' purchase intentions. In this study, respondents felt that the person closest to them thought and hoped they would purchase food and beverages online. This hypothesis is also supported by previous studies (Hasbullah et al., 2016; Kusumaningsih et al., 2019) that prove that there is a relationship between subjective norms and purchase intentions. Kusumaningsih et al. (2019) explained that the intention to buy food is influenced by people who have an influence on respondents. This finding is supported by positive words from a group playing an important role in the acceptance of those closest to them (Hasbullah et al., 2016).

The quality of a product, especially food and beverages, becomes an important value for the consumer satisfaction factor, which will have an impact on respondents' buying interests. In this study, healthy food \& beverages were not a consideration in respondents 
choosing food \& beverages for transactions in online food delivery applications. This can be seen in most respondents aged 17-25 years, who are not overly concerned about healthy food and beverages. According to Oktavia (2020), consumers aged 17-25 years are less concerned about health, with habits of eating fast food, soft drinks, and a lack of vegetables and fruit.

A development in service with an internet network system can affect respondents' buying intentions. In this study, respondents felt the ease of getting food and beverages through online food applications. This can be seen in the expectations of respondents purchasing food and beverages within one week. During the pandemic, people were advised not to leave their homes, and most respondents took advantage of the convenience of getting food and beverages through online food delivery applications. This hypothesis is supported by previous research findings that e-service quality has an impact on purchase intention; this proves that ease of use, fast response, informative and efficient service, excellence, and a sense of security when using e-service can increase purchase intention (Kalia et al., 2016; Ahmed et al., 2017).

An awareness of respondents regarding their health condition, both physically and mentally, can influence the respondents' purchase intention for the type of food and beverages that they will buy. In this study, respondents felt that it was important for them to get health from the food and beverages they ate. This can be seen from the hopes and desires of respondents to buy food \& beverages within one week. The current findings are supported by a previous study that there is a relationship between health consciousness and purchase intentions with organic food purchases (Meireles, 2018). Therefore, it can be said that with the existence of health consciousness, the purchase intention for organic food is higher. Health consciousness plays an important role in purchase intention and consumption of food (Abdulsahib et al., 2019).

The respondents' intention to buy something through electronic media and the internet will influence the actual actions of the buying activity. Based on this study, respondents expect and will buy food and beverages for one week or more. Food and beverages purchasing activities through online food applications since Covid-19 was identified high. This hypothesis is supported by Wee et al. (2014), in which the purchase intention of a food product significantly influences the probability of actual buy behaviour. Ofori and AppiahNimo (2019) also confirmed that online purchase intention has a strong causal relationship with the actual buying behaviour of spending more time and money to shop through online media.

\section{Conclusions}

Based on this study, there are still concerns from users regarding the level of application security used in online food delivery. The matter of concern is related to personal information. For this reason, it is necessary for online food application service providers to improve customer data security and periodically educate users themselves. In using this service, it turns out users prefer it because they personally want to use the application. This study shows that not everyone closest to the respondent expects respondents to buy food and beverage online. Thus, the introduction of online food delivery application services will be more appropriate if it is more focused on the individual directly than through the testimony of the closest people to that individual.

With most respondents aged from 17-25 years, the results of the study are more likely to show that healthy food and beverage is not the main factor in purchasing. This certainly needs to be a concern for online food application service providers to combat the dangers of obesity so that it can be prevented as early as possible. This can be done by advertising 
or socialising for weight control and maintaining health from a young age, especially the age of 17-25 years, to trigger consumer awareness to maintain their physical condition. Moreover, food beverage businesses should provide healthy food \& beverages that are attractive and innovative while conducting campaigns to consume healthy food and drinks. As an example, Lemonilo is one of the pioneers of technology-based healthy food and beverages in Indonesia; they provide food, cooking spices, and drinks and campaign to consume healthy food through cooperation with several cafes and ropang (grilled bread) (Handoko, 2018).

This study shows a lack of respondents who will conduct online food and beverage transactions within one week, so the advice for owners of online food delivery applications is to do a campaign directed at users in order to increase customer online purchase intentions. Moreover, transactions are carried out in a week only as many as 1-3 times. This is also a challenge for online food application service providers and food and beverage business owners, so that they can provide promotions through applications or create applications for this service with a gamification approach. Thus, the use of this application is expected to be more interesting and increase transactions in the purchase of food \& beverages.

This study still has limitations, namely that the results of this study were obtained from respondents at residences in mostly Java. By carrying out further research in other environments, the researchers believe they will get results and new views that are more detailed. In addition, this research has not yet thoroughly examined the convenience of using smartphone-based technology applications, so there is still room for research development by looking at this technology from a different perspective. With the development of this research, it will be able to provide a more complete picture of application-based online food delivery services.

\section{References}

Abdulsahib, J.S., Eneizan, B., Alabboodi, A.S., 2019. Environmental Concern, Health Consciousness and Purchase Intention of Green Products: An Application of Extended Theory of Planned Behavior. The Journal of Social Sciences Research, Volume 5(4), pp. 868-880

Ahmed, W., Hussain, S., Jafar, M.S., Latif, W.U., Sultan, M.U., JianZhou, Y., 2017. Impact of EService Quality on Purchase Intention Through Mediator Perceived Value in Online Shopping. Journal of Information Engineering and Applications, Volume 7(8), pp. 24-28

Amirullah, 2020. Terawan Jelaskan Alasan Setujui Status PSBB Banten. Available Online at https://nasional.tempo.co/read/1330785/terawan-jelaskan-alasan-setujui-statuspsbb-banten

Annur, C.M., 2020a. Riset: Belanja Online Indonesia Tumbuh 3,7 Kali Lipat di 2025. Available Online at https://katadata.co.id/ekarina/digital/5e9a495b679e8/risetbelanja-online-indonesia-tumbuh-37-kali-lipat-di-2025

Annur, C.M., 2020b. Gojek dan Grab Sebut Order GoFood dan GrabFood Naik Meski Ada Corona. Available Online at https://katadata.co.id/berita/2020/03/24/gojek-dangrab-sebut-order-gofood-dan-grabfood-naik-meski-ada-corona

Asvial, M., Mayangsari, J., Yudistriansyah, A., 2021. Behavioral Intention of e-Learning: A Case Study of Distance Learning at a Junior High School in Indonesia due to the COVID19 Pandemic. International Journal of Technology, Volume 12(1), pp. 54-64

Badan Pusat Statistik, 2019. Statistik E-Commerce 2019. Available Online at https://www.bps.go.id/publication/2019/12/18/fd1e96b05342e479a83917c6/stati stik-e-commerce-2019.html 
Berawi, M.A., 2020. Empowering Healthcare, Economic, and Social Resilience during Global Pandemic Covid-19. International Journal of Technology, Volume 11(3), pp. 436-439

Berawi, M.A., 2021. Innovative Technology for Post-Pandemic Economic Recovery. International Journal of Technology, Volume 12(1), pp. 1-4

Blow, J., Patel, S., Davies, I.G., Gregg, R., 2019. Sociocultural Aspects of Takeaway Food Consumption in a Low-socioeconomic Ward in Manchester: A Grounded Theory Study. BMJ Open, Volume 2019(9), pp. 1-8

Cahyadi, R.K., 2020. 7 Tips Agar Bisnis Restoran dan Kedai Kopi (F\&B) Bertahan di Masa Corona. Available Online at https://www.gadjian.com/blog/2020/04/17/tipsrestoran-masa-corona

Candra, S., Cahyono, H., Wibowo, R.A., Sutopo, T., 2020a. Acceptance of the Use of Social Media: Case of Linkedin in Indonesian Netizen. International Journal of Scientific and Technology Research, Volume 9(1), pp. 1451-1461

Candra, S., Nuruttarwiyah, F., Hapsari, I.H., 2020b. Revisited the Technology Acceptance Model with E-Trust for Peer-to-Peer Lending in Indonesia (Perspective from Fintech Users). International Journal of Technology, Volume 11(4), pp. 710-721

Chen, M., 2009. Attitude Toward Organic Foods Among Taiwanese as Related to Health Consciousness, Environmental Attitudes, and the Mediating Effects of A Healthy Lifestyle. British Food Journal, Volume 111(2), pp. 165-178

CNN Indonesia, 2020. Jumlah Kasus Corona Meningkat, Restoran Cuma Layani Take Away. Available Online at https://www.cnnindonesia.com/ekonomi/20200330101014-92488161/jumlah-kasus-corona-meningkat-restoran-cuma-layani-take-away

Coppola, D., 2021. E-commerce worldwide-Statistics \& Facts. Available Online at https://www.statista.com/topics/871/online-shopping

Curvelo, I.C.G., Watanabe, E. A. de M., Alfinito, S., 2019. Purchase Intention of Organic Food Under the Influence of Attributes, Consumer Trust and Perceived Value. Revista de Gestão, Volume 26(3), pp. 198-211

Gefen, D., Straub, D., Boudreau, M.-C., 2000. Structural Equation Modeling and Regression: Guidelines for Research Practice. Communications of the Association for Information Systems, Volume 4(7), pp. 1-77

Hair, J.F., Hult, G.T.M., Ringle, C.M., Sarstedt, M., 2014. A Primer on Partial Least Squares Structural Equations Modeling (PLS-SEM). SAGE Publishing, California, USA

Hair, J.F., Risher, J.J., Sarstedt, M., Ringle, C. M., 2019. When to Use and How to Report the Results of PLS-SEM. European Business Review, Volume 31(1), pp. 2-24

Hasbullah, N.A., Osman, A., Abdullah, S., Salahuddin, S.N., Ramlee, N.F., Soha, H.M., 2016. The Relationship of Attitude, Subjective Norm and Website Usability on Consumer Intention to Purchase Online: An Evidence of Malaysian Youth. Procedia Economics and Finance, Volume 35, pp. 493-502

Hastuti, R.K., 2020. Selera Makanan Masyarakat Berubah Saat PSBB, Ini Rinciannya. Available Online at Indonesia. https://www.cnbcindonesia.com/tech/20200506194317-37-156834/seleramakanan-masyarakat-berubah-saat-psbb-ini-rinciannya

Ismaya Gourmet Shop, 2020. From Our Kitchen to Your Home. Available Online at https://www.ismaya.com/eat-drink/ismaya-gourmet-shop

JW Marriot Hotel Official, 2020. JW Marriot Jakarta 'Iftar dan Hampers' Tahun 2020. Available Online at https://www.instagram.com/p/B_CiWe8BVGa

Kalia, P., Arora, R., Kumalo, S., 2016. E-Service Quality, Consumer Satisfaction and Future Purchase Intentions in e-Retail. E-Service Journal, Volume 10(1), pp. 24-41 
Kemenkes Republik Indonesia, 2020. Info Infeksi Emerging Kementerian Kesehatan RI. Available Online at https://covid19.kemkes.go.id/downloads

Kirchherr, J., Charles, K., 2018. Enhancing the Sample Diversity of Snowball Samples: Recommendations from a Research Project on Anti-Dam Movements in Southeast Asia. PLoS ONE, Volume13(8), pp. 1-17

Kock, N., 2020. WarpPLS User Manual: Version 7.0. ScriptWarp Systems: Laredo, Texas, USA Kementerian Komunikasi dan Informatika (KOMINFO), 2019. Kemkominfo: Pertumbuhan e-Commerce Indonesia Capai 78 Persen. Available Online at http:///content/detail/16770/kemkominfo-pertumbuhan-e-commerce-indonesiacapai-78-persen/0/sorotan_media

Kusumaningsih, D., Irianto, H., Antriyandarti, E., 2019. Effects of Health Consciousness and Environmental Attitude on Intention Towards Organic Food Purchase. In: IOP Conference Series: Materials Science and Engineering, 633, 012052

Meireles, P., 2018. The Impact of Health Consciousness on the Purchase Intention of Organic Food: The Moderating Effect of Perceived Store Image. Master's Dissertation, Graduate Program, Universidade Católica Portuguesa, Portugal

Memery, J., Angell, R., Megicks, P., Lindgreen, A., 2015. Unpicking Motives to Purchase Locally-Produced Food: Analysis of Direct and Moderation Effects. European Journal of Marketing, Volume 49(7-8), pp. 1207-1233

Nystrand, B.T., Olsen, S.O., 2020. Consumers' Attitudes and Intentions Toward Consuming Functional Foods in Norway. Food Quality and Preference, Volume 80, pp. 1-11

Ofori, D., Appiah-Nimo, C., 2019. Determinants of Online Shopping Among Tertiary Students in Ghana: An Extended Technology Acceptance Model. Cogent Business \& Management, Volume 6(1), pp. 1-20

Oktavia, N., 2020. Perilaku Tidak Sehat Remaja. Available Online at https://www.kompasiana.com/niken50662/5e7b37b3097f36592a6a66d2/perilakutidak-sehat-remaja

Pertiwi, S.W.P., 2020. Transaksi Nontunai McDonald's Melonjak Selama Pandemi Covid-19. Available Online at https://mediaindonesia.com/read/detail/304707-transaksinontunai-mcdonalds-melonjak-selama-pandemi-covid-19

Pramudita, B.A., 2020. Dipukul Covid-19 Habis-habisan, 10 Sektor Bisnis Ini Paling Babak Belur. Available Online at https://www.wartaekonomi.co.id/read280898/dipukulcovid-19-habis-habisan-10-sektor-bisnis-ini-paling-babak-belur/1

Putsarna, D.V., 2020. Arti PSBB yang Dibuat untuk Cegah Penyebaran Corona di Indonesia. Available Online at https://tirto.id/arti-psbb-yang-dibuat-untuk-cegah-penyebarancorona-di-indonesia-eMXT

Rahmaningtyas, A., Hartono, S., Suryantini, A., 2017. Factors Affecting Online Purchasing of Local Food. Agro Ekonomi, Volume 28(2), pp. 189-204

Rauniar, R., Rawski, G., Yang, J., Johnson, B., 2014. Technology Acceptance Model (TAM) and Social Media Usage: An Empirical Study on Facebook. Journal of Enterprise Information Management, Volume 27(1), pp. 6-30

Sate Taichan "Goreng" Official, 2020. Sistem Order Online Sate Taichan "Goreng" Selama Masa Pandemi. In Sate Taichan "Goreng" Official Instagram. Available Online at https://www.instagram.com/p/B_ojVBjnfGf

Sekaran, U., Bougie, R., 2016. Research Methods for Business: A Skill Building Approach, 7th Edition. Wiley: New Jersey, Amerika

Sembiring, L.J., 2020. Sri Mulyani: Sangat Berat, Ekonomi RI Bisa Minus 0,4\% di 2020. Available Online at https://www.cnbcindonesia.com/news/20200401094117-4148944/sri-mulyani-sangat-berat-ekonomi-ri-bisa-minus-04-di-2020 
Shin, Y.H., Hancer, M., 2016. The Role of Attitude, Subjective Norm, Perceived Behavioral Control, and Moral Norm in the Intention to Purchase Local Food Products. Journal of Foodservice Business Research, Volume 19(4), pp. 338-351

Soenarso, S.A., 2020. Survei Moka: Food and Beverages Jadi Industri yang Paling Terdampak dari Covid-19. Available Online at https://industri.kontan.co.id/news/survei-mokafood-and-beverages-jadi-industri-yang-paling-terdampak-dari-covid-19

Suhartanto, D., Helmi Ali, M., Tan, K.H., Sjahroeddin, F., Kusdibyo, L., 2019. Loyalty Toward Online Food Delivery Service: The Role of e-Service Quality and Food Quality. Journal of Foodservice Business Research, Volume 22(1), pp. 81-97

Sulek, J.M., Hensley, R.L., 2004. The Relative Importance of Food, Atmosphere, and Fairness of Wait: The Case of a Full-service Restaurant. Cornell Hotel and Restaurant Administration Quarterly, Volume 45(3), pp. 235-247

Taherdoost, H., 2016. Sampling Methods in Research Methodology; How to Choose a Sampling Technique for Research. International Journal of Academic Research in Management, Volume 5(2), pp. 18-27

Tamtomo, A.B., 2020. INFOGRAFIK: Beda PSBB dengan Karantina Wilayah. Available Online at https://www.kompas.com/tren/read/2020/04/01/180300065/infografik-bedapsbb-dengan-karantina-wilayah

Taylor, D.B., 2020. A Timeline of the Coronavirus Pandemic. The New York Times

Ueasangkomsate, P., Santiteerakul, S., 2016. A Study of Consumers' Attitudes and Intention to Buy Organic Foods for Sustainability. Procedia Environmental Sciences, Volume 34, pp. 423-430

Urbach, N., Ahlemann, F., 2010. Structural Equation Modeling in Information Systems Research using Partial Least Squares. Journal of Information Technology Theory and Application, Volume 11(2), Available at https://aisel.aisnet.org/jitta/vol11/iss2/2

Wee, C.S., Ariff, M.S.B., Zakuan, N., Tajudin, M.N.M., Ismail, K., Ishak, N., Haji, L.T., 2014. Consumers Perception, Purchase Intention and Actual Purchase Behavior of Organic Food Products. Review of Integrative Business \& Economic Research, Volume 3(2), pp. 378-397

WHO, 2005. Statement on the meeting of the International Health Regulations (2005) Emergency Committee regarding the outbreak of novel coronavirus 2019 (n-CoV) on 23 January 2020. Available Online at https://www.who.int/news-room/detail/23-012020-statement-on-the-meeting-of-the-international-health-regulations-(2005)emergency-committee-regarding-the-outbreak-of-novel-coronavirus-(2019-ncov)

Xiao, A., Yang, S., Iqbal, Q., 2018. Factors Affecting Purchase Intentions in Generation Y: An Empirical Evidence from Fast Food Industry in Malaysia. Administrative Sciences, Volume 9(4), pp. 1-16

Zikmund, W.G., Babin, B.J., Carr, J.C., Griffin, M., 2013. Business Research Methods, 9th ed. Cengage Learning: Massachusetts, Amerika 